\title{
Potential Impacts of Climate Change on Livelihood and Food Security of Artisanal Fisherfolks in Lagos State, Nigeria
}

\author{
Siyanbola Adewumi Omitoyin ${ }^{1} \&$ Fregene Ben $\operatorname{Tosan}^{2}$ \\ ${ }^{1}$ Department of Animal Science and Fisheries Management, Bowen University, Iwo, Nigeria \\ ${ }^{2}$ Department of Wildlife and Fisheries Management, University of Ibadan, Nigeria \\ Correspondence: Siyanbola Adewumi Omitoyin, Department of Animal Science and Fisheries Management, \\ Bowen University, Iwo, Nigeria. E-mail: sbomitoyin@yahoo.com
}

Received: March 14, 2012 Accepted: April 10, 2012 Online Published: July 26, 2012

doi:10.5539/jas.v4n9p20 URL: http://dx.doi.org/10.5539/jas.v4n9p20

\begin{abstract}
The artisanal fishery occupies a significant position in the Nigerian economy providing employment for about $5.8 \%$ of the Nigerian population and supplying $81.9 \%$ of the total domestic fish production. However, climate change is modifying the distribution of fish species with changes in habitat, size, species diversification and productivity. The study, therefore, examined the potential impact of climate change on livelihood and food security of artisanal fisherfolks in Lagos State, Nigeria
\end{abstract}

A stratified sampling technique was used to select 88 fishing communities in Lagos State. A total of 311 respondents were interviewed using structured questionnaire. Data collected include socio-economic characteristics, livelihood parameters, fish species and productivity data while climatic data was obtained from the weather station and meteorology department. Data were analysed using descriptive statistics and stochastic frontier catch function analysis.

The result of the analysis showed that there were changes in temperature and rainfall pattern which is a deviation from the normal trend. Variation in species diversity and abundance was also observed.

There were other sources of livelihood engaged in either as primary or secondary occupation.

There is the need to put in place strategies that will mitigate the effect of climate change

Keywords: climate change, livelihood, food security, fisherfolks, Lagos State

\section{Introduction}

Fisheries and aquaculture have very important roles for food supply, food security, livelihoods and income generation from local to global levels. Some 42 million people work directly in the sector, with the great majority in developing countries. Adding those who work in associated processing, marketing, distribution and supply industries, the sector supports several hundred million livelihoods. Aquatic foods have high nutritional quality, contributing 20 percent or more of average per capita animal protein intake for more than 2.8 billion people, mostly from developing countries. Allison E. H, et al (2009). In Nigeria, the artisanal fishery occupies a significant position in the economy contributing $4 \%$ to the total GDP, providing employment for about $5.8 \%$ of the Nigerian population and supplying $81.9 \%$ of the total domestic fish production. (FDF, 2007).

Climate change is projected to impact broadly across ecosystems, societies and economies, increasing pressure on all livelihoods and food supplies, including those in the fisheries and aquaculture sector. Food quality will have a more pivotal role as food resources come under greater pressure and the availability and access to fish supplies will become an increasingly critical development issue (FAO, 2008).

According to Nelson G (IFPRI/) 2009, Agriculture's vulnerability (fisheries and aquaculture inclusive) to climate change will put millions of people in developing countries at greater risk of poverty, hunger, and malnutrition thus impacting on their food security status.

The contribution of fisheries to food security is on the increase. Food security according to FAO 1996 is defined as "access by all people at all times to the food needed for healthy and active life". Fish protein has a significant nutritional role in Nigeria contributing as much as $4.8 \%$ of total protein consumption and about $30 \%$ of annual protein consumption. Apparent fish consumption in 1995 was estimated to be a little over 7.0kg per caput (FAO, 
1996) although projected per caput consumption for that year was $13.19 \mathrm{~kg}$ (FOS 1996). Based on information in the fourth and fifth National Development Plans (1980/85, 1990), 40\% of animal protein consumed by the average Nigerian come from fish.

In Low-Income Food-Deficit Countries (LIFDCs), some communities are dependent on fish not only for animal protein, but also as a source of micro-nutrients, minerals and essential fatty acids. Although, theoretically, these proteins and nutrients could come from other sources, in isolated fisheries dependent communities alternatives are likely to be more expensive, if they are available at all.

\section{Materials and Method}

\subsection{Study Area}

Lagos state is one of the maritime states in Nigeria. It has an area of 3,577 square kilometers and lies in the south west geopolitical zone of the country (Figure 1). It is bounded on the West by the Republic of Benin, in the North and East by Ogun State and in the South by the Guinea Coast of the Atlantic Ocean. It has an extensive network of Lagoon and Creeks in Lagos, Ikorodu, Badagry and Epe local governments (Udo and Mamman 1993) which covers about 22 percent or 786.94 square kilometers of the total area, and a coast line of about $180 \mathrm{~km}$ and a handful of streams and rivers. Lagos state extends approximately from latitude $6^{0} 20^{\prime}$ North to $6^{0} 40^{\prime}$ North and from latitude $2^{0} 45^{\prime}$ East to $4^{0} 20^{\prime}$ East (Figure 2). All these provide a unique opportunity for fishing activities, which in fact has always been a traditional occupation among the people.

A stratified sampling technique was used to select 88 fishing communities in Lagos State. A total of 311 respondents were interviewed using structured questionnaire. Data collected include socioeconomic characteristics, livelihood parameters, fish species, and productivity data while climatic data was obtained from the weather station and meteorology department. Data were analysed using descriptive statistics.

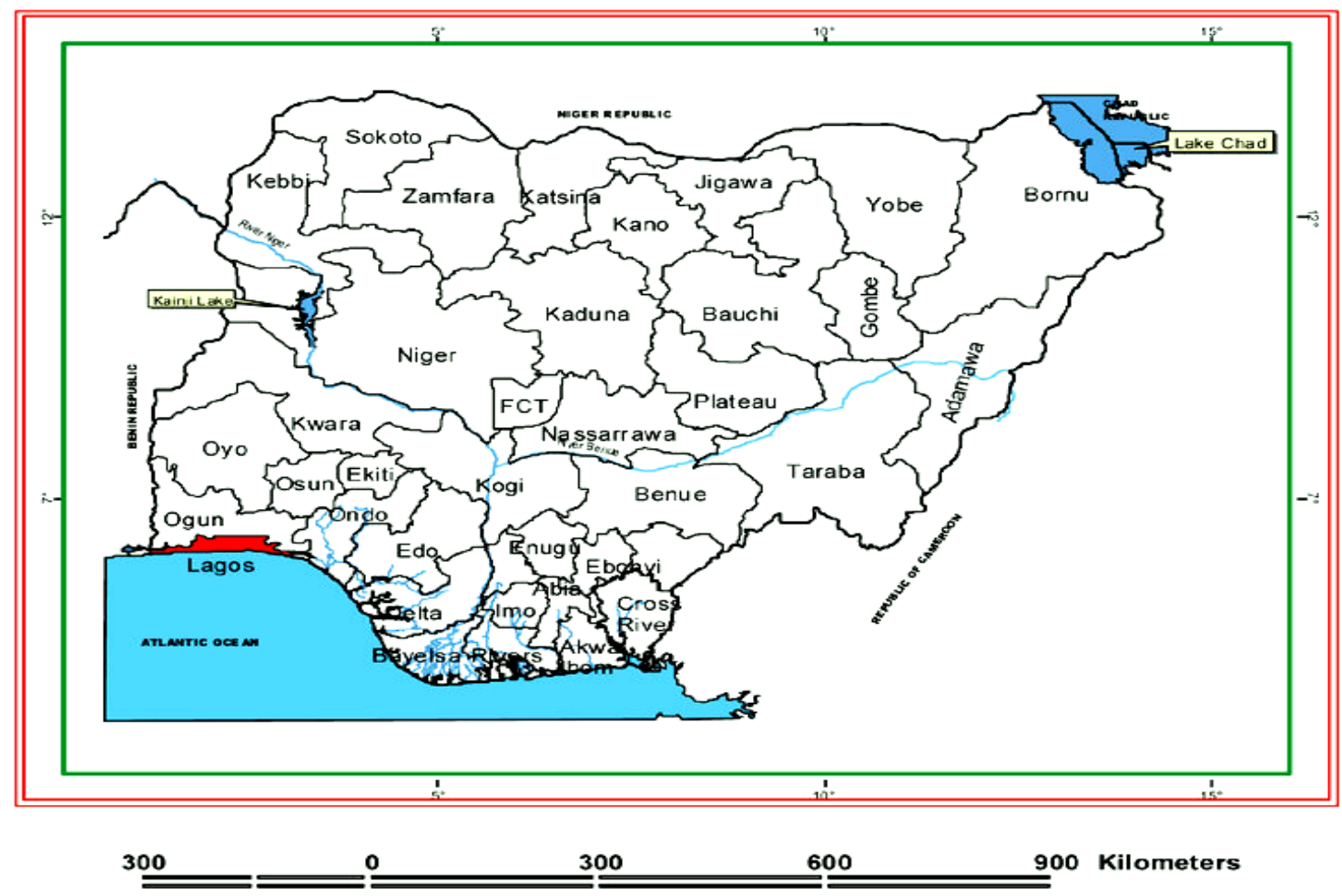

Figure 1. Map of Nigeria showing Lagos State 


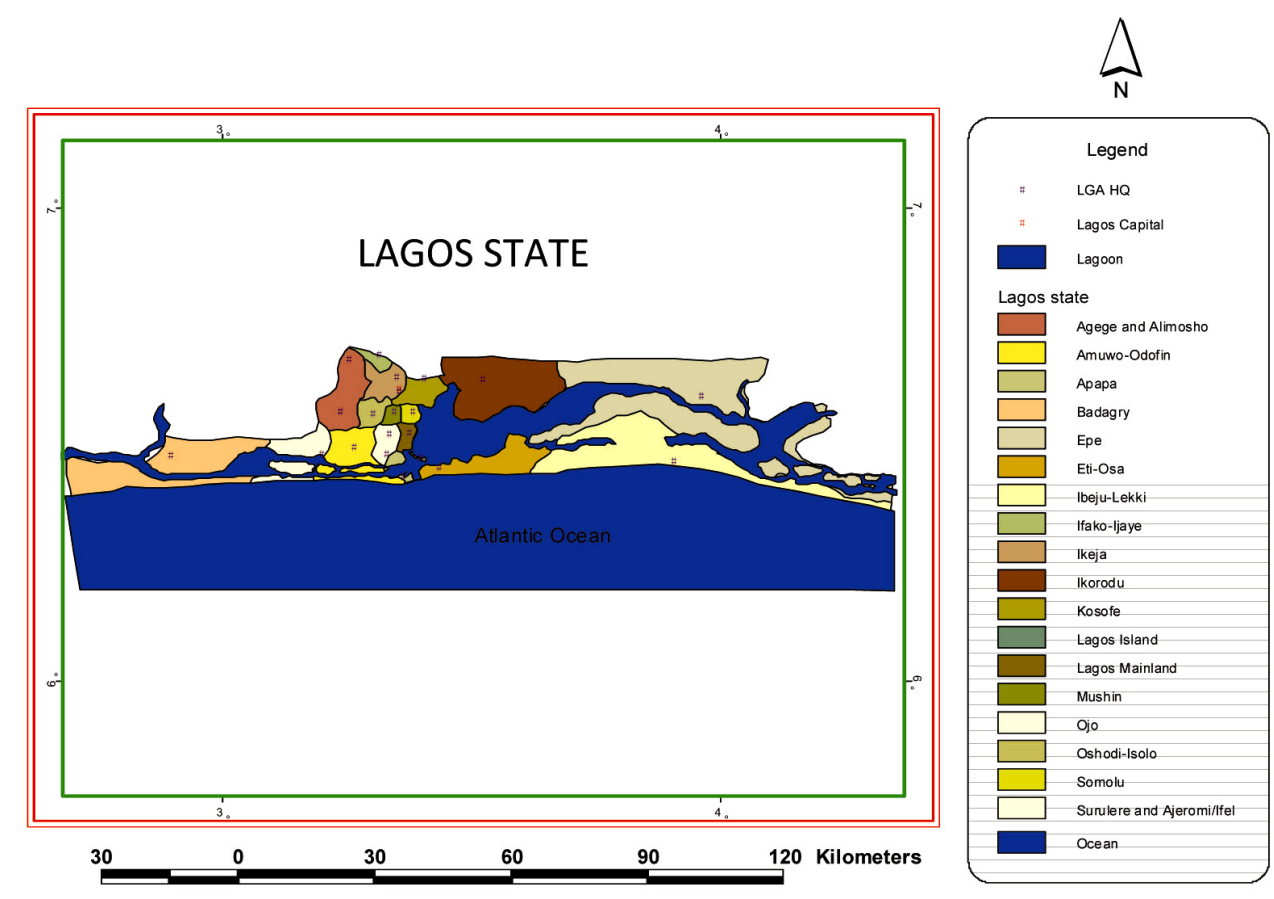

Figure 2. Map of Lagos State

\section{Result and Discussion}

\subsection{Socio-economic Analysis}

The distribution of respondents by gender (Table 1) shows that $68.8 \%$ were males while $31.2 \%$ were females. This shows that more men are household heads.

Table 1. Distribution of Respondents by Gender, Marital status, Age group and Educational Level

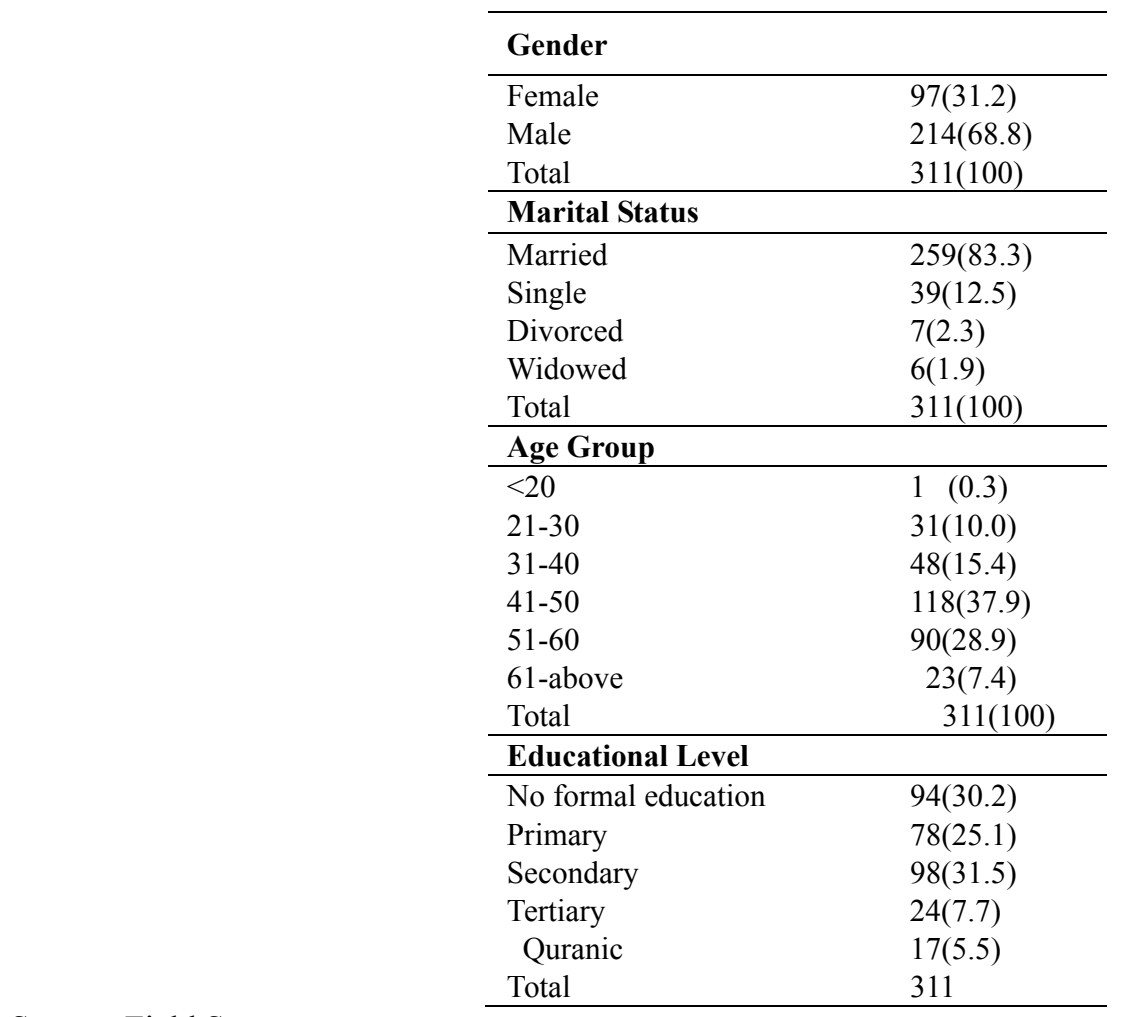

Source: Field Survey 
The marital status profile shows that $83.3 \%$ were married, $12.5 \%, 2.3 \%$ and $1.9 \%$ were single, divorced or widowed. The age of the household head ranged between 18 and 75 years with a mean of 46.7 year and standard deviation of 10.56 (Table 6). The general distribution showed that majority of the respondent (37.9\%) fell within the $41-50$ years age bracket (Table 1) while $0.3 \%, 10 \%, 15.4 \%, 28.9 \%$ and $7.4 \%$ represents the age groups of $<20$ years, $21-30$ years, 31-40 years , $51-60$ years and $>60$ years of age were $7.4 \%$. This trend shows the proportion of age group distribution involved in active fishing in the study area. The age of an individual has implications on the experience and decision making ability.

The survey results showed that the highest proportion of the respondents $(31.5 \%)$ had secondary education (Table 1). Those with no formal education were $30.2 \%, 5.5 \%$ had Quranic education, $25.1 \%$ had only primary education while $7.7 \%$ had OND and NCE certificates. These shows that most respondents $64.3 \%$ could read and write

The findings of the socio-economic parameters is similar to the result of the work carried out by Abduh and Delgado, 1999, Fregene B.T, 2002, Horemans B, 2006 and Omitoyin et al 2009.

In the study area, as in other African setting, most households were made up of a man, wife/wives, children and extended family members. All these form the household size. The result of the study shows that $68.5 \%$ of the respondent had household size of between 2 and 6; (Table 2) 20.3\% had household size greater than 6 while $11.2 \%$ were single household. The minimum household size is 1 , the maximum is 10 while the mean household size is 4.3 with standard deviation 2.5 (Table 6). This is similar to the findings of Khandker, 1988 which infers that a large family can mean that the fisherman is more likely to work off fishing because relatives can substitute for his labour and supervision and could also suggest that he is more likely to work at home because some relatives might work off the farm to supplement family income.

The multi ethnicity nature of the study area is evident by the distribution of the various ethnic groups with the Yorubas dominating the fishing areas with 78.1\%. This is followed by Egun 9.3\% and Ibos $8.4 \%$. Other ethnic groups represented include Isoko (0.3\%), Ijaw (2.3), Ilaje (0.3\%) and Hausas (1.3\%) (Table 2).

\subsection{Primary and Secondary Occupation}

The occupations of the fisherfolks during the wet and dry seasons and their distribution are presented in Table 3 . Seventy six point two percent of the respondents had fishing as their primary occupation in the wet season while $23.8 \%$ had other activities as their primary occupation while during the dry season, $78.8 \%$ had fishing as their primary occupation and $21.2 \%$ engaged in other activities as their primary occupation.

Fishing is the primary occupation in both wet and dry season. The trend however shows fishing as more prevalent in the dry season than in the wet season. This conforms to the findings of Akanni et al (2007) that fishing is the predominant activity in Marine, lagoon and freshwater water bodies of Lagos State but more people are involved during the dry season than the raining season. Other activities engaged in as secondary occupation to augment their livelihood and enhance their food security are crop production, trading, livestock production, tailoring, fish processing, artisans, civil service, labour and hunting (Table 3). This is similar to the finding of Anosike and Coughenour (1990) cited by Awoyemi (1999), Berachi (2003) and Akanni et al (2007) that by diversifying, the fisherfolk may use resources more efficiently and promote sustainability. Beyond this, other livelihood activities has been known to be a risk reduction strategy used by artisanal fisherfolks. Secondary livelihood activities apart from fishing engaged in by the fisherfolks, the mean income received and standard deviation of other secondary activities is presented in Table 4. It was observed that female fisherfolks engaged in more than two other livelihood activities apart from fishing at a time unlike their male counterparts. This could be largely due to the higher subsistence needs of the women within the household as well as high risk coping strategies imposed on them by their life-style of multiple goals.

\subsection{Fishing and Marketing Activities}

The distribution of fisherfolks by type of fishing engaged in is presented in Figure 3. Sixty two percent (62\%) of the respondent are involved in capture fisheries only $26 \%$ are involved in culture fisheries while $12 \%$ are involved in both capture and culture fisheries.

The percentage of fisherfolks involved in culture fisheries i.e. aquaculture is on the increase. This is due to livelihood diversification which may not be unconnected with dwindling catch from open water as a result of change in climate which is noticeable in reduction in fish size, diversity and number. The distance covered by the fishermen before appreciable quantity of fish is caught is between one and seventy kilometers with a mean of $13.93 \mathrm{~km}$ and standard deviation of $9.69 \mathrm{~km}$ (Table $5 \& 6$ ). About $56.3 \%$ of the respondents travel as far as $15 \mathrm{~km}$ for their fishing activities which is an indication that majority of the fisherfolks fish around the same area. This is 
as a result of inadequate technology, high cost of gear and other inputs and inadequate credit facilities. This is similar to the findings of Jiddawi (2001) in Tanzania and Squire et al (2002) in Malaysia.

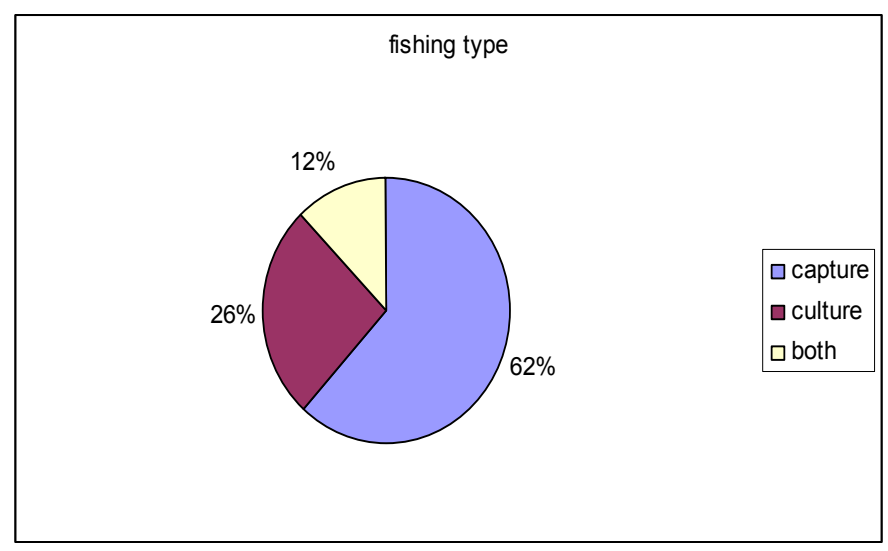

Figure 3. Distribution of respondents by type of fishing engaged in

Table 2. Distribution of Respondents according to Household size and Ethnicity

\begin{tabular}{|c|c|}
\hline & General Freq. \\
\hline \multicolumn{2}{|l|}{ Household Size } \\
\hline 1 & $35(11.2)$ \\
\hline 2 & $87(26.0)$ \\
\hline 3 & $15(4.8)$ \\
\hline 4 & $46(14.8)$ \\
\hline 5 & $31(10.0)$ \\
\hline 6 & $40(12.9)$ \\
\hline 7 & $21(6.8)$ \\
\hline 8 & $19(6.1)$ \\
\hline 9 & $14(4.5)$ \\
\hline 10 & $9(2.9)$ \\
\hline Total & $311(100)$ \\
\hline \multicolumn{2}{|l|}{ Ethnicity } \\
\hline Ibo & $26(8.4)$ \\
\hline Yoruba & $243(78.1)$ \\
\hline Egun & $29(9.3)$ \\
\hline Isoko & $1(0.3)$ \\
\hline Ijaw & $7(2.3)$ \\
\hline Ilaje & $1(0.3)$ \\
\hline Hausa & $4(1.3)$ \\
\hline Total & $311(100)$ \\
\hline
\end{tabular}

Source: Field Survey 
Table 3. Distribution of Respondents by Primary and Secondary Occupation in Wet and Dry Season and Water Body

\begin{tabular}{|c|c|c|}
\hline & Wet season Freq. & Dry season Freq. \\
\hline \multicolumn{3}{|l|}{ Primary Occupation } \\
\hline Fishing & $237(76.2)$ & $245(78.8)$ \\
\hline Crop production & $37(11.9)$ & $9(2.9)$ \\
\hline Trading & - & $16(5.1)$ \\
\hline Livestock production & $2(0.6)$ & $6(1.93)$ \\
\hline Hunting & - & - \\
\hline Tailoring & $5(1.6)$ & $3(0.96)$ \\
\hline Fish processing & $30(9.6)$ & $18(5.8)$ \\
\hline Civil servant & - & $14(4.5)$ \\
\hline \multicolumn{3}{|l|}{ Secondary Occupation } \\
\hline Fishing & $213(68.5)$ & $80(25.7)$ \\
\hline Crop production & $89(28.6)$ & 191(61.4) \\
\hline Trading & $9(2.9)$ & $7(2.3)$ \\
\hline Livestock production & - & $17(5.5)$ \\
\hline Hunting/artisan/labour & - & $16(5.1)$ \\
\hline
\end{tabular}

Source: Field Survey

Table 4. Contribution of other Sources of Livelihood (Primary and Secondary Occupation of Fisherfolks)

\begin{tabular}{llllll}
\hline Other Livelihood & Freq. & $\begin{array}{l}\text { Min } \\
(\mathrm{N})\end{array}$ & $\begin{array}{l}\text { Max } \\
(\mathrm{N})\end{array}$ & $\begin{array}{l}\text { Mean } \\
(\mathrm{N})\end{array}$ & $\begin{array}{l}\text { Standard } \\
\text { Deviation }\end{array}$ \\
\hline Income from Crop production & 113 & 100.00 & 250,000 & 9838.05 & 28962.58 \\
Income from Livestock production & 62 & 50.00 & 60,000 & 5306.13 & 11495.45 \\
Income from Trading & 78 & 200.00 & 100,000 & 11210.26 & 17654.39 \\
Income from Hunting & 53 & 50.00 & 50,000 & 2258.49 & 8192.99 \\
Income from Civil Service & 21 & $2,800.00$ & 56,000 & 28180.95 & 18032.40 \\
Income from Wage/Labor & 1 & 3500.00 & 3,500 & 3500 & - \\
Income from Artisans & 12 & 650.00 & 8,500 & 5804.17 & 2631.32 \\
Income from Tailoring & 15 & 500.00 & 10,000 & 4166.67 & 3554.01 \\
\hline Soure: Fin Survey & & & & & \\
\hline
\end{tabular}

Source: Field Survey

(Income calculated from other sources as presented by the respondents)

N $150=\$ 1$

The fishermen's catch were basically sold to fish mongers (47.3\%), individuals (37\%), while $15.1 \%$ sold to both fish mongers and individuals and only $0.6 \%$ sold to cooperative societies (Table 5).This pattern of sale may be due to the fact that most fisherfolks are aided financially by the fish mongers and individuals, thus they are committed to selling their catches to them.

The point of sale of fish caught was either by the water side (36\%) at the market $(29.6 \%)$ or in the house (11.3\%) while some dispose off their fish at both market and water side (17.7\%) or at market and house 5.5\% (Table 5). This is similar to the practice in Tanzania (Bagachwa and Maliyamkono, 1994) and Fiji Island (Reddy, 2006)

The numbers of craft acquired by respondents from the study area is presented in Table 7. Fifty four point seven percent of the respondents had no craft at all, 35.4\% had only one craft, $8.9 \%$ had between two crafts 6 crafts 
respectively. It was observed that only fewer fisherfolks had craft which definitely had effect on their catch, income and by implication their livelihood. Anon, 2001 and Berachi, 2003 had a similar experience in Tanzania.

Table 5. Distribution of Respondents by Type of Fishermen, How Fish is Sold, Location, Fishing Type and Distance

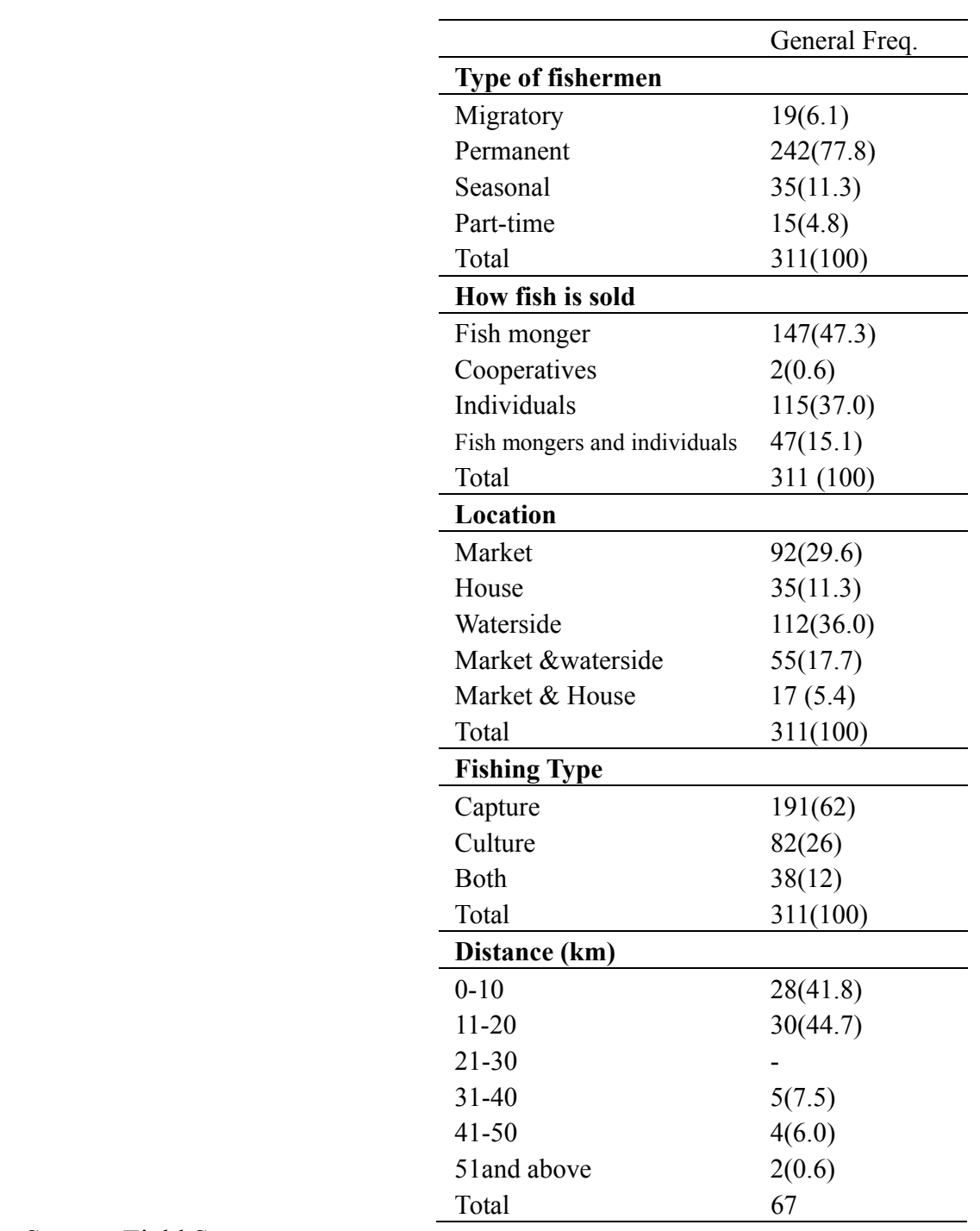

Source: Field Survey

(Figures in parentheses are in percentages)

Table 6. Descriptive Statistics of Age, Household size and Distance

\begin{tabular}{cccccc}
\hline & Freq. & Minimum & Maximum & Mean & Std. Deviation \\
\hline Age (years) & 311 & 18 & 75 & 46.7 & 10.56 \\
House hold size ( No) & 311 & 1.00 & 10.00 & 4.2958 & 2.53 \\
Distance $\quad(\mathrm{km})$ & 311 & 1.0 & 70 & $13.93 \mathrm{~km}$ & 9.69 \\
\hline
\end{tabular}

Source: Field Survey, 
Table 7. Distribution of Respondents by Number of Crafts and Engine Acquired

\begin{tabular}{ll}
\cline { 2 - 2 } No of Craft & General freq \\
\hline None & $170(54.7)$ \\
1 & $110(35.7)$ \\
2 & $16(5.1)$ \\
3 & $11(3.5)$ \\
4 & $2(0.6)$ \\
6 & - \\
Total & $2(0.6)$ \\
\hline No of Engine acquired \\
\hline None & $2411(100)$ \\
\hline 1 & $60(19.3)$ \\
2 & $4(1.3)$ \\
3 & - \\
4 & $2(0.6)$ \\
\hline Total & $311(100)$ \\
\hline
\end{tabular}

Source: Field Survey

(Figures in parentheses are in percentages)

Only $19.3 \%$ of the total respondent had acquired one engine; $1.3 \%$ had two while $0.6 \%$ had 4 engines. $78.8 \%$ of the respondent do not have engine at all (Table 7). The use of engine would facilitate improve catch since they would be able to move further into the water to get better catch The distribution of fisherfolks by the number of engine acquired in the water bodies shows that majority of the fisherfolks do not have an engine to power their craft which invariably places a limitation on the distance they can cover especially in the marine and lagoon communities. The same is the experience in Gambia and Malaysia (Jammeh, 2002; Squires et al, 2002).

\subsection{Climatic Factors}

The rainfall pattern in Figure 4 shows great variation over time in terms of volume and intensity. High volume of rain water might have led to flooding and consequently washing away of breeding grounds and loss of some fish species (Figure 6). This observation is in line with the observation of FAO, 2008a who reported that climate change is modifying the distribution of marine and freshwater species and that species are being displaced towards the poles and are experiencing changes in the size and productivity of their habitats. It is corroborated by Sharp, 2003 in his submission that climate-related dynamics have had serious consequences on evolution of species, fisheries variability and the livelihood of fisherfolks.

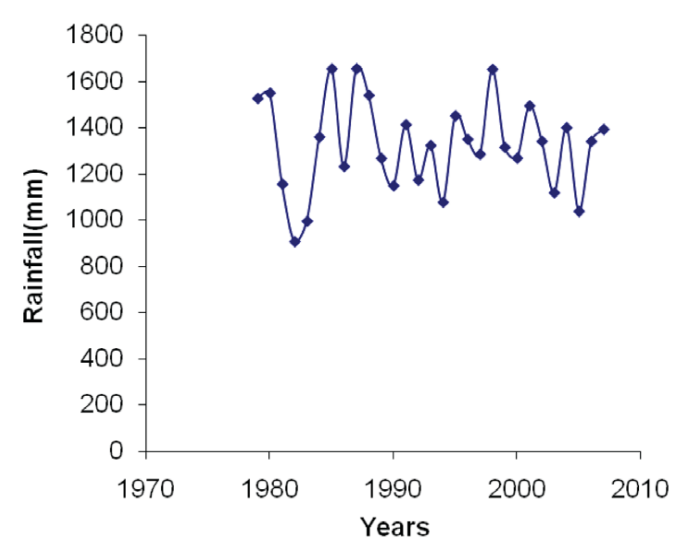

Figure 4. Rainfall distribution in the study area 
The trend of temperature pattern for about 30 years clearly showed high fluctuation overtime (Figure 5). Invariably, since fishing depends on wild populations whose variability depends on environmental processes governing the supply of young stock, their feeding and predation conditions through the life cycle; climate change might have had strong implication on fish breeding, egg hatchability, fry survival, food availability and fish distribution pattern. Fish are poikilothermic animals therefore any change in habitat temperatures would significantly influence metabolism, growth rate, total production, reproduction seasonality, reproductive efficacy, and susceptibility to diseases and toxins as observed by Sharp (2003). Climate change-induced temperature variations would thus have a much stronger impact on the spatial distribution of fishing activities and on their productivity and yields as observed in Figure 6.

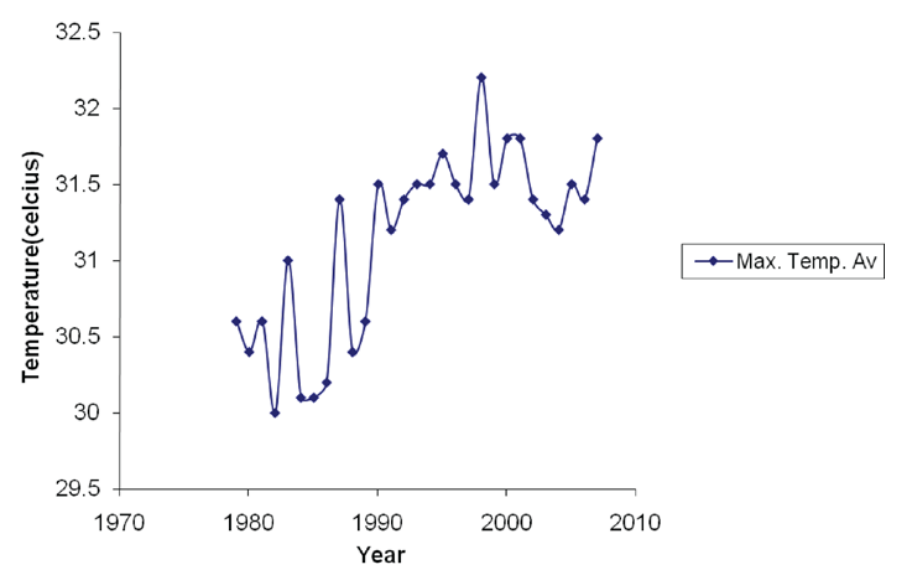

Figure 5. Temperature distribution in the study area

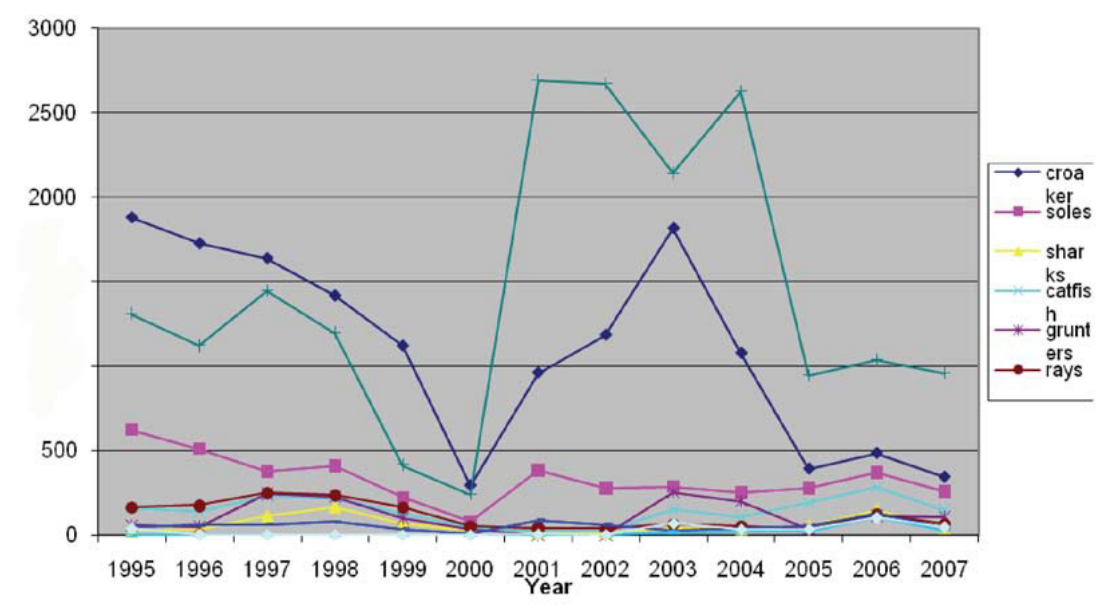

Figure 6. Fish production from inshore fishing by species (FDF 2007)

The fish production pattern as shown in Figure 6 revealed a high fluctuation and variation in catch.

This variation and change in diversity is in accordance with the findings of Cheung, W. W. L et al (2009) which says Global climate change is expected to affect marine fisheries productivity because of changes in water temperature, ocean currents and other ocean conditions. Marine fisheries are an important food source, and changes in the total amount or geographic distribution of fish available for catch could affect food security.

\subsection{Implication on Food Security}

In Nigeria with $5.8 \%$ of the population employed in artisanal fisheries and the sub sector providing $81.9 \%$ of the total fish production, decrease in catch as a result of climate change have a devastating effect on employment and multiplier effects on income, food consumption (protein intake), malnutrition especially in children, increased prices, livelihood and general wellbeing making many more fisherfolks food insecure. This is corroborated by (FAO, 2008b) which stated that Climate change has both direct and indirect impacts on fish stocks that are exploited commercially with direct effects acting on physiology and behavior and altering growth, 
development, reproductive capacity, mortality, and distribution while Indirect effects alter the productivity, structure, and composition of the ecosystems on which fish depend for food and shelter.

Climate change has impact on fisherfolk already living in poverty thus alternative sources of livelihood has to be sorted for. Allison et al (2005) attest to the fact that the majority of the world's 200 million full and part-time fisherfolk Nigeria inclusive (fishers, fish processors, traders and ancilliary workers) and their dependents live in areas vulnerable to human-induced climate change, or depend for a major part of their livelihood on resources whose distribution and productivity are known to be influenced by climate variation. Sadovy 2005, McClanahan et al. 2008 and World Fish Center 2008, also said millions of small-scale fisherfolk (fishers, fish processors, traders and ancillary workers) in the developing world are among the most vulnerable to climate change. Since according to Allison et al (2005) the livelihoods of fisherfolk living near the waterbodies are highly adapted to extensive fluctuations and the systems are climate-change sensitive, there is the need to reduce vulnerability to the impacts of adverse employed by the fisherfolks along side with reduction of post harvest losses through the utilization of zero energy and environmentally friendly processing and preservation method because Fisheries is critical for Poverty reduction, Economic development and Food security

\section{Conclusion}

Improving food security requires putting in place strategies that will mitigate the effect of climate change through making better use of the little fish caught by reducing post-harvest losses through effective methods of preservation and value addition to the products thus increasing the percentage of fish used for direct human consumption, improving access to micro-credit to purchase efficient gear so that the same area is not fished over and over again and use of better gear to reduce fish trash and those discarded at sea. Coping strategies which include alternative sources of livelihood and diversification into farmed fish / aquaculture is also been encouraged.

\section{References}

Abduh, A., \& Delgado, C. L. (1999). Determinants of Non Farm Earnings of Farm based Husbands and Wives in Northern Ghana. American Journal of Agricultural Economics, 81(1), 117-130. http://dx.doi.org/10.2307/1244455

Akanni, K. A., \& Akinwumi, J. A. (2007). Determinants of Variations in Fish Catch levels in Artisanal Fishing of Lagos State, Nigeria. Research Journal of Fisheries and Hydrobiology, 2(1), 1-12.

Allison E. A, Adger, W. N., Marie-Caroline, B., Brown, K., Conway, D., Dulvy, N. K., ... Reynolds, J. D. (2005). Effects of climate change on the sustainability of capture and enhancement fisheries important to the poor: analysis of the vulnerability and adaptability of fisherfolk living in poverty. Fisheries Management Science Programme, Department for International Development Summary Report (Project No. R4778J) SCIENCE SERIES.

Allison, E. H., Perry, A. L., Badjeck, M. C., Adger, W. N., Brown, K., Conway, D., ... Dulvy, N. K. (2009). Vulnerability of National Economies to the impacts of climate change on fisheries. Fish and Fisheries, 10(2), 173-196.

Anon. (2001). Frame Survey Report Ministry of Natural Resources and Tourism, Fisheries Division United Republic of Tanzania. pp. 23.

Awoyemi, T. T. (2000). A Gender Analysis of Economic Efficiency in Cassava-Based Farm Holdings in South-Western Nigeria: Unpublished PhD Thesis, Department of Agricultural Economics, University of Ibadan.

Bagachwa, M. D., \& Maliyamkono, T. L. (1994). Fisheries and Development in Tanzania Macmillan Press Ltd, London, United Kingdom. pp. 10-13.

Berachi, I. G. (2003). Bioeconomic Analysis of Artisanal Marine Fisheries of Tanzania (Mainland) Unpublished Msc Thesis in International Fisheries Management, Department of Norwegian, College of Fishery Science, University of Tromsø, Norway. pp. 46.

Brander, K. M. (2007). Global fish production and climate. Proceedings of the National Academy of Science of the United States of America PNAS, 104(50), 19709-19714. http://dx.doi.org/10.1073/pnas.0702059104

Cheung, W. W. L., Lam, V. W. Y., Sarmiento, J. L., Kearney, K., Watson, R., Zeller, D., \& Pauly, D. (2009). Redistribution of Fish Catch by Climate Change: A Summary of a New Scientific Analysis. Pew Ocean Science Series. Proc. Natl. Acad. Sci. U. S. A., 104(50), 19709-14. http://dx.doi.org/10.1111/j.1365-2486.2009.01995.x 
Federal Department of Fisheries. (2007). Fishery Statistics of Nigeria 4th Edition Federal Dept. of Fisheries Abuja. pp. 49.

Federal Office of Statistics. (1996). Annual abstracts of statistics 1996 Abuja. pp. 60.

Food and Agricultural Organisation. (1996). Institutional Credit for Sustainable Fish Marketing, Capture and Management in Asia and the Pacific. FAO Fisheries Report, Rome, 540, 70.

Food and Agricultural Organisation. (2008a). Climate Change, Energy and Food High Level Conference on Food Security: The Challenges of Climate Change and Bio-energy: Climate Change for Fisheries and Aquaculture Technical Background Document HLC/08/BAK/6.

Food and Agricultural Organisation. (2008 $)$. Report of the FAO Expert workshop on climate change. Implication for Fisheries and Aquaculture; FAO Fisheries Report No 870.

Fregene, B. T. (2002). Poverty Assessment in Fishing Communities in Lagos State, Nigeria. Unpublished PhD Thesis. Dept of wildlife and Fisheries Management.

Horemans, B. (2006). Education for Rural people: Sustainable Fisheries Livelihood Programme-FAO/DFID. pp. 12. http://www.oceansatlas.com/fishatlas/generated/teu00101.htm

Jammeh, M. E. (2002). Access to Finance in the Artisanal Fishery Sector of the Gambia. Gambia Social Development Fund. (SDF) Presentation Made at the Workshop on Artisanal Fisheries and the World Markets (11-12 April 2002): Administration of Agricultural Credit Schemes with Reference to the AFDP Credit Programme. pp. 14.

Jiddawi, N. S. (2001). Status and Trends of Tanzania's Marine Artisanal Fisheries In Coastal Communities and the Indian Ocean's Future Conference Chennai India. pp. 14.

Khandker, S. R. (1988). Input Management Ability, Occupational Patterns and Farm Productivity in Bangladesh Agriculture: The Journal of Development studies, 24(2), 214-231. http://dx.doi.org/10.5897/JDAE11.058

McClanahan, T. R. Cinner, J. E., \& Maina, J. (2008). Conservation action in a changing climate Conservation Letters, 1, 53.

Nelson, G. (2009). Agricultural Adaptation to Climate Change. In the Developing World: What will it cost; IN Report from the International Food Policy Research Institute (IFPRI) Workshop on Climate Change and Fisheries and Aquaculture: "Options for decision makers" FAO Headquarters, Rome, 7-9 April 2008 http://www.enaca.org/modules/news/article.php?storyid=1753 (27th May 2010)

Omitoyin S. A., \& Fregene, B. T. (2009). Effect of Micro-credit on sustainable livelihood of artisanal fisherfolks in Lagos lagoon Nigeria. African Journal of Livestock Extension, 7, 70-76

Reddy, M. (2004). Economic Analysis of Artisanal Fisheries in Fiji: Issues of Profitability and Sustainability. South Pacific Studies, 22, 15-17.

Reddy, M. (2006). Technical Efficiency in Artisanal Fisheries: Evidence from a Developing Country Working Paper School of Economics: The University of the South Pacific Suva, Fiji. pp. 23.

Sadovy, Y. (2005). Trouble on the reef: the imperative for managing vulnerable and valuable fisheries. Fish and Fisheries, 6, 167-185. http://dx.doi.org/10.1111/j.1467-2979.2005.00186.x

Sharp, G. D. (2003). Future climate change and regional fisheries: a collaborative analysis. FAO Fisheries Technical Paper, No. 452 Rome FAO. 2003. p. 75 (ISBN 92-5-105016-3).

Squires, D., Grafton, Q., Ferdous Alam, M., \& Omar, I. H. (2002). Technical Efficiency in the Malaysian Gill Net Artisanal Fishery Discussion Paper 98-26, Dept. of Economics, University of California, San Diego, pp. 37.

World Fish Center. (2008). The Millennium Development Goals: Fishing for a Future: Reducing poverty and hunger by improving and aquaculture. http://www.seaaroundus.org/ClimateChange/images/Pew\%2 